\title{
Anticipated Loss and Mourning in Adolescence: Based on Film 'Monster Calls'
}

\author{
Youn Jeong Choi ${ }^{1}$ and Jee Hyun $\mathrm{Ha}^{2}$ \\ ${ }^{1}$ Department of Psychiatry, Konkuk University Medical Center, Seoul, Korea \\ 2Department of Psychiatry, School of Medicine, Konkuk University, Seoul, Korea
}

\section{청소년기 예견된 상실과 애도: ‘몬스터 콜’을 중심으로}

\author{
최 윤 정'하 지 현 ${ }^{2}$ \\ 건국대학교병원 정신건강의학과, ${ }^{1}$ 건국대학교 의학전문대학원 정신건강의학교실2
}

Loss is a universal phenomenon that anyone can experience, and mourning is a process of adapting to a new phase of life accompanied by loss. Loss can cause psychological trauma, which in turn can have a negative impact on subsequent lives. Loss of important objects such as parents, especially those experienced in children and adolescents, is important for mourning experience and has a significant impact on the mental structure of post-loss adulthood. In addition, adolescence is a creative period in which a new identity has to be formed away from the previous stage of development, accompanied by inevitable loss. 'A monster calls' is a film contains a developmental process of mourning for the teenager in the predictive loss situation. The author analyzed 'A monster calls' and gained insight into the mental characteristics of adolescents and studied the developmental mourning process. In conclusion, it was found that accepting the inevitability of the relationship and the inevitability of the loss, and undergoing the mourning process of internalizing and identifying the lost object through developmental mourning is an essential element in the development and maturation of all human beings as well as adolescents.

Psychoanalysis 2018;29(3):54-62

KEY WORDS: Loss $\cdot$ Mourning $\cdot$ Adolescent $\cdot$ Development.

Received: April 24, 2018 Revised: June 8, 2018 Accepted: June 8, 2018

Address for correspondence: Jee Hyun Ha, MD, PhD

Department of Psychiatry, School of Medicine, Konkuk University, 120-1 Neungdong-ro, Gwangjin-gu, Seoul 05030, Korea

Tel: +82-2-2030-7569, Fax: +82-2-2030-7748, E-mail: jhnha@naver.com

\section{서 론}

상실은 누구나 경험할 수 있는 보편적인 현상이며 애도는 상실을 동반하는 새로운 삶의 국면에 적응해 가는 과정이다. 상실은 심리적 외상을 유발하여 이후의 삶에도 지속적으로 부정적인 영향을 끼칠 수도 있다. 하지만 애도를 통하여 발 달적인 심리적 변형을 이룬다면 성숙의 계기가 될 수 있다. 프로이트(Freud 1917)는 소아기에 경험한 상실이 성인기에 발생하는 우울증의 위험요인이 된다고 했다. 그래서 아동과 청소년기에 경험할 수 있는 부모와 같은 중요한 대상의 상 실은 충분한 애도 경험이 중요하다. 상실을 맞닥뜨리는 것,

This is an Open Access article distributed under the terms of the Creative Commons Attribution Non-Commercial License (https://creativecommons.org/licenses/by-nc/4.0) which permits unrestricted non-commercial use, distribution, and reproduction in any medium, provided the original work is properly cited.
받아들이는 것, 소화하는 것을 포함하는 애도의 전 과정은 상실을 경험하는 당시뿐만 아니라 이후 성인기의 정신구조 에도 상당한 영향을 미친다.

프로이트(Frued 1917)는 'Mourning and Melancholia'에 서 처음 애도를 중요한 주제로 다륐다. 이후 애도는 멜라니 클라인(Klein 1940)의 'Mourning and Its Relation to ManicDepressive States'를 통해 임상 및 발달의 중요한 과제 중 하 나로 그 의미가 확장되었다. 그녀는 전체 또는 부분적 대상 에 대한 애착 및 정서 상태를 유아의 일차적 대상과 관련시 켰는데, 대상의 상실 및 함입(introjection), 대상에 대한 공 격성을 강조했다. 클라인(Klein 1940)은 애도가 인간의 심리 발달에 없어서는 안 될 중요한 한 단계이며 동시에 마음의 유동적이고 창조적인 형태의 기원이라고 했다. 볼비(Bowlby 1963)는 애착이 심리 발달과 성장을 위한 근본적인 요소이 고 애도를 통해서 대상의 상실을 견딜 수 있는 능력은 지속 
적인 성장을 위한 일차적 조건이라고 하였다. 즉, 그는 상실 을 견딜 수 있는 능력의 정도가 정신 병리의 발생과 발달 정 지에 있어 결정적인 요인이 된다고 하였다. 이처럼 많은 학자 들이 애도에는 병적 측면뿐 아니라 발달적 측면도 있다고 하 였다. 애도에 실패하게 되면 정신 병리의 발생 위험성이 증가 되지만, 불가피한 상실을 경험하면서 성공적인 애도를 하는 경우에는 이전보다 한결 건강하고 성숙한 인격을 형성하고 정신발달에 있어 중요한 기초를 마련할 수 있다.

상실과 애도는 청소년기 발달에도 영향을 미친다. 청소년 기는 소아기와는 확연히 구별되는 발달 단계로 많은 학자들은 이 시기에 특징적인 심리 내적 과제를 갖고 있다는 것을 파악 했다. 청소년기에는 자신과 타인에 관한 지각에 있어 큰 영향을 주는 신체 및 성적인 변화가 발생하고(Paikoff와 Brooks-Gunn 1991), 애착의 대상에 대한 점진적인 분리 및 개별화가 일어난 다(Bowlby 1969; Weiss 1991). 또 인지능력이 성숙하며 (Fonagy와 Target 1997), 동료 집단에 대한 소속과 또래 집단 의 영향력이 강해지는 시기이다(Bukowski와 Hoza 1989). 이 중 저자들이 중요하게 본 것은 청소년기의 분리-개별화 현 상이다. 안나 프로이트(Freud 1960)는 청소년의 리비도가 부모로부터 분리되고 새로운 대상을 향하는 지점에 있으므 로, 과거의 대상에 대한 애도는 필연적이라 하였다. 청소년 기에는 이상적 부모상의 동일시로부터 발생한 자기애적 과 대사고와 전능감을 포기하면서 고유한 정체성을 형성하는 과정을 거친다. 피터 블로스(Blos 1967)는 이를 '제2의 개별화 의 과정(the second individuation process of adolescence)'이 라 하였는데 '제 2 의 개별화 과정'도 '제 1 의 개별화 과정' (Mahler 등 1975)과 마찬가지로 성장과 변화를 위한 애도의 과정이 필수적이라고 했다. 청소년기의 분리-개별화 과정은 상실을 통해 촉발되며 애도 과정에 실패할 경우 청소년기에 고착되거나 성인기까지 이어지는 외상적 기억을 형성할 수 도 있다. 그렇게 되면 심한 불안과 우울, 자존감 저하, 사회 적 위축 등이 유발되고 건강한 성격 형성에도 부정적인 영 향을 줄 위험이 있다. 만일 자아의 성숙이 온전하지 않은 청 소년이 예견된 상실(predictive grief)의 상황에 처해 있다면, 이를 스스로 직면하고 인정하는 것은 어려운 일이며 나아가 이후의 발달에 있어 부정적인 요소가 될 수 있다. 그러나 예 견된 상실을 직면하고 대응하는 과정을 거치면서 선행 요인 으로 멈춰 있던 발달을 재개하는 긍정적인 계기가 될 가능 성도 있다.

저자들은 이와 같은 문제의식을 갖고 2017년에 한국에서 상영된 영화 '몬스터 콜스(A monster calls, 한국 개봉명: 몬 스터 콜)'를 소재로 청소년기의 예정된 상실과 이를 수용하는 과정을 연구하고자 한다. 이 영화는 패트릭 니스(Patrick Ness)
의 동명 소설 '몬스터 콜스'(Ness 2011)를 원작으로 한다. 원 작은 영국의 소설가 시본 도우드(Siobhan Dowd)가 유방암 으로 사망하기 전 마지막으로 구상했던 것을 패트릭 니스가 이어받아 완성해 2011년에 발간된 바 있다. 이 작품은 '엄마 의 죽음'이라는 예견된 애도(predictive grief) 상황에 처한 열 두 살 소년이 ‘주목나무 괴물’을 만나게 되면서 성장하는 과 정을 다루었다. 전통적으로 정신분석에서 중요한 주제가 되 어 온 '애도'를 다루고 있을 뿐만 아니라, 의미심장한 꿈, 환상, 무의식 등을 여러 가지 영화적 장치들 속에서 섬세하게 표현 하여 청소년의 정신적 특성에 대한 통찰을 얻기에 좋은 재 료를 제공한다.

\section{본 론}

\section{몬스터 콜의 줄거리}

열두 살 소년 코너는 다섯 살 때 부모가 이혼한 후 말기 암 환자인 엄마와 둘이 살고 있다. 코너는 학교에서 투명인간 취급을 받으며 해리라는 친구로부터 괴롭힘도 당한다. 또래 보다 작고 위축된 채 생활을 하면서 밤마다 엄마가 코너의 손에 의지한 채 절벽에 매달려 있다 결국 절벽 밑으로 떨어 져 사라지는 악몽에 시달린다. 외할머니는 이른 결혼으로 딸 의 꿈을 포기하게 만든 코너의 아빠와 코너를 달갑게 생각 하지 않는다. 코너도 엄격한 외할머니를 싫어해 함께 살자는 제안을 거부한다. 아빠는 이혼 후 미국으로 가서 결혼을 했 고, 새 가정을 꾸렸지만 일 년에 한 번씩 코너를 만나러 온 다. 코너는 아빠가 그를 데리고 미국으로 가기를 소망하지만 아빠는 현실적으로 어렵다고 거절을 한다. 반복되는 악몽에 서 깨어난 어떤 날 밤 12 시 07 분, 주목나무의 형상을 한 괴물 이 코너를 찾아온다. 괴물은 코너에게 앞으로 세 가지의 이 야기를 들려주겠다고 하며, 다음 네 번째 이야기는 코너가 해야 한다고 말한다.

첫 번째는 권력을 차지하기 위해 왕을 죽이고 왕자와 결 혼하려고 하는 왕비의 이야기다. 왕비는 의붓아들인 왕자와 결혼하기 위해 왕자의 연인을 죽였고, 왕자는 왕비를 물리치 고 왕위를 차지하여 성왕이 되었다. 그러나 사실은 알려진 것과 달랐다. 왕비는 왕도 왕자의 연인도 죽이지 않았으며 왕자를 사랑했을 뿐 악한 존재는 아니었다. 정작 연인을 살 해한 것은 왕자 자신으로, 권력을 차지하기 위하여 연인을 살해하고 죄를 여왕에게 뒤집어쓰운 것이다. 악행을 저질렀 음에도 불구하고 백성들에게는 사랑받는 왕이 되어 행복한 삶을 산다. 이야기의 이면에 감추어져 있던 잔혹한 진실에 코너는 혼란스러워 한다. 괴물은 코너에게 세상에 절대적인 선과 악은 없으며 모든 사람은 그 중간에 있다고 말한다. 
다음 날 엄마의 증상이 나빠져 입원하자 외할머니 집으로 옮기게 되었다. 다시 12시 07분이 되고 몬스터가 약제사에 대한 두 번째 이야기를 들려준다. 마을 사람들의 신임을 얻 은 목사는 약제사를 미워하여 설교 시간에 공개적으로 비난 하였다. 약제사는 동네 사람들의 외면을 받아 경제적인 어려 움을 겪는다. 약제사는 교회 뒤 뜰에 있던 주목나무를 약재 로 쓰게 해 달라고 목사에게 부탁하지만 거절당한다. 그 후 목사는 희귀병에 걸린 두 딸을 잃게 될 위기에 처해, 약제사 를 찾아가 죽어가는 딸을 살려 달라고 간청한다. 약제사에게 신앙까지 버릴 수 있다고 하지만 약제사는 목사의 부탁을 거 절하였고 결국 목사의 두 딸은 죽게 된다. 코너는 약제사를 비난하지만, 괴물은 약제사가 아니라 되려 명백한 이유 없이 약제사를 비난하고 신앙을 버리겠다고 한 목사를 비난하며 교회를 부수기 시작한다. 괴물은 코너에게 더 파괴해야 할 것이 있는지 묻고 파괴할 것이 남아 있다면 스스로의 힘으로 직접 파괴할 것을 권한다. 코너의 분노와 공격성이 폭발되며 코너는 괴물과 함께 교회를 부수기 시작한다. 환상에서 현실 로 돌아와 정신을 차려 보니 부수고 있는 것은 목사의 교회가 아니라 현실 속 외할머니의 집 안 가구들이었다.

다음 날 낮 12 시 07 분, 괴물은 학교에서 점심식사 중이던 코너를 찾아와 세 번째 이야기를 들려주는데 다른 사람들로 부터 존재를 무시당한 뒤 투명인간이 된 사람의 이야기였다. 투명인간은 학교에서 코너를 무시하던 친구들이 코너를 부 르던 별명이기도 했다. 코너는 이 이야기를 듣고 각성하여 평소 자신을 괴롭히던 해리를 때려눕힌다.

엄마의 병이 깊어진 것을 깨달은 코너는 괴물을 찾아가 엄 마를 살려 달라고 부탁한다. 그러나 괴물은 그건 불가능하다 고 말하며 자신은 코너가 불러낸 존재이고, 엄마가 아닌 코 너를 치유하기 위해 존재한다고 말한다. 괴물은 코너에게 이 제 네 번째 이야기를 할 시간이라고 하며, 매일 밤 꾸던 악몽 에서 코너가 숨기고 있던 진실을 이야기할 것을 요구한다. 하지만 코너는 진실이 자신을 죽게 할 것이라고 두려워하며 저항한다. 마침내 코너는 절벽에서 엄마의 손을 놓았다는 것 을 고백한다. 죽어가는 엄마를 보는 것에 큰 고통을 느꼈고 차라리 엄마가 빨리 죽기를 바라는 마음을 가졌던 것이다. 코너는 이 같은 생각이 매우 나쁘고 용서받지 못할 마음이라 고 여겼다. 이 생각 때문에 엄마가 죽게 된 것이라는 생각도 했다. 괴물은 코너에게 그것은 무수한 생각 중 하나에 불과하 다고 하며 삶은 생각이 아니라 행동을 통해 이루어진다고 말 한다. 비로소 코너의 가슴을 짓누르던 답답함이 사라지고, 사 라진 코너를 찾아온 외할머니와 화해하고 엄마가 암으로 죽 어 가고 있다는 현실을 인정할 수 있게 되었다. 마침내 자신 의 내면과 현실을 직면할 수 있게 되었고 병실로 찾아가 엄
마가 죽기 전, 사랑한다는 말을 한다. 엄마가 사망하고 외할머 니와 함께 살게 된 코너는 엄마가 쓰던 방을 사용하게 된다.

\section{네 개의 이야기와 애도의 준비}

괴물이 들려주는 세 개의 이야기와 코너가 말하는 네 번째 이야기는 모두 코너의 꿈이라고 볼 수 있다. 네 개의 이야기 는 상징적으로 청소년기 정신발달과 준비되지 않은 자아가 예견된 상실을 수용하고 더 높은 차원으로 발달해 나가는 과 정을 잘 표현하고 있다.

첫 번째와 두 번째 꿈에서 괴물이 들려준 이야기는 겉으 로 보이는 현상이 감춰진 진실과는 다를 수 있다는 것을 보 여줬다. 이는 소아기에서 청소년기로 이행하는 과정에서 발 달하는 인지 발달 과정을 반영한 것이다. 소아기에는 착함과 나쁨이라는 이분법적인 사고방식으로 세상을 이해한다. 그 러나 괴물은 꿈을 통해서, 세상은 이러한 이분법적 논리로는 이해될 수 없는 회색 지대가 있다는 것을 알려준다. 또 가시 적인 현상의 이면에는 고려해야 할 여러 측면들이 있다는 것 도 인식하도록 한다. 코너는 처음에는 괴물이 들려준 이야기 를 이해하지 못하고 혼란을 느끼지만 점차 그 의미를 알아 간다. 이처럼 인지능력의 성숙이 있었기에 아빠가 함께 살자 는 자신의 제안을 거절한 것을 적절하게 수용할 수 있다. 즉, 자신이 거절당한 것 자체가 아빠에게 버림받는 것은 아니라 고 깨달을 수 있으며 자신을 태생적으로 태어날 필요가 없 는 존재로 여기지 않을 수 있다. 또 겉으로는 무섭고 차가워 보이는 외할머니가 사실은 코너와 엄마를 아끼며 나름의 방 식으로 사랑하는 것이라는 것도 이해하게 된다. 두 번째 꿈 은 꿈이라는 환상에서 시작되지만 현실 속에서 외할머니 집 거실에 있는 물건들을 부수는 것으로 전환된다. 청소년기에 는 현실과 환상의 경계가 모호하다. 자아의 현실감각은 유지 되지만 소아기에서 두드러지는 환상의 우세도 존재하는데, 이는 청소년기에 몽상과 창조적 사고가 증가하는 것과 관련 있다. 환상이 우세할 때 현실로부터 퇴각하여 자기만의 세계 에만 몰두하고 이를 강박적으로 반추할 수 있다. 또 기괴한 사고와 비현실적 환상이 망상의 수준으로 악화될 위험도 있 다. 이 같은 현상은 일시적인 퇴행 현상의 하나로 정상적인 청소년기에도 관찰된다. 코너는 가족이나 친구 어느 누구에 게도 마음을 터놓고 지내지 못하였고 병든 엄마와 단 둘이 외 떨어진 집에서 살고 있었다. 마땅한 보호자 없이 사회적으로 고립된 환경 속에 생활하면서 코너의 내적 사고와 환상이 활 발하게 작동했을 것이다. 꿈속에서 이 같은 환상의 영역은 더 강화되고 평소 억제되었던 공격성과 파괴적 충동이 발현되 기도 한다. 두 번째 꿈에서는 공격성의 폭주가 꿈의 경계 안 에서만 발생하는 것이 아니라 외할머니의 가구를 부수는 현 
실로 전환된다. 그리고 세 번째 꿈을 통해 코너는 자신의 존 재를 무시당하며 살고 있다는 것을 깨닫고 해리를 때려눕히 면서 “나는 투명인간이 아니야!”라고 소리를 친다. 두 번째 꿈에서 세 번째 꿈으로 이어지는 과정은, 억제되었던 자아와 공격적 충동이 꿈을 통해 현실과 접점을 만들어가는 과정으 로 해석할 수 있다. 두 번째 꿈에서 코너는 외할머니의 가구 를 부수지만 그 공격성의 의미와 대상은 뚜렷하지 않다. 외 할머니에 대한 원망과 두려움은 있지만 그녀의 물건을 부술 만한 것은 아니기 때문이다. 다만 이를 통하여 코너에게 내 재된 공격성이 있으며 충동이 강렬해지면서 결국 현실로 돌 출될 수 있음을 암시한다. 시도 때도 없이 코너를 괴롭히던 해리는 "너에게 할 수 있는 내 최후의 일격은 무관심이야. 안 녕. 코너."라고 말하며 갑자기 코너에게 관심을 거두게 된다. 세 번째 꿈은 이례적으로 낮 12 시 07분, 점심시간에 일어난 다. 백일몽처럼 낮에 혼자 학교 식당에서 식사를 하던 코너에 게 괴물이 찾아온다. 해리의 무관심이 그 촉발점이 되어 코 너의 파괴적 충동은 백일몽의 환상으로 강렬해지면서 자아 의 통제를 벗어나게 된다. 이처럼 코너의 본능적 공격성은 괴물의 몸을 빌어 환상 속에서 현실로 외현화되었다. 이 같 은 양상은 임상에서도 흔히 관찰할 수 있는데, 자아가 취약 한 정상 청소년이 자아의 경계가 흔들리면서 현실 검증력이 저하되고 환상에 몰입한다. 청소년의 자아 발달이 공고하지 않을 때 충동을 자아가 성공적으로 제어하지 못하게 되고 깨어 있는 낮 시간에도 코너가 보인 행동과 같은 충동적 폭 주가 충분히 일어날 개연성이 있다.

이 같은 자아의 강한 흔들림은 연쇄반응을 일으켜 더 깊 은 곳에 억제되어 있던 코너의 무의식적 죄책감을 의식의 표 면 위로 끌어올렸다. 네 번째 꿈을 통해 코너는 반복되는 악몽 에서 자신이 절벽에 매달린 엄마의 손을 놓았다는 것을 의식 화할 수 있었다. 자신이 절벽에 매달린 엄마의 손을 놓았다는 것은 코너에게 용납할 수 없는 죄의식을 불러일으켰고 이를 억압하여 무의식에 봉인해 왔다. 꿈작업에서는 죄의식과 공격 적 충동이 충돌하고 있었지만, 잠재몽에 머무른 채로는 발현 몽으로 의식될 수는 없었다. 코너는 기억과 느낌이 의식화되 지 않도록 억제하는 데 지나치게 많은 에너지를 투여했기 때 문에 온전한 일상 생활을 하기 어려웠던 면도 있었다. 그 결과 매일 악몽을 꾸고 위축된 정동을 보이고 충동적인 행동을 하 는 불균등한 자아 기능을 가졌던 것으로 해석할 수 있다.

네 번의 꿈은 결국 코너가 회피하고자 했던 예기된 상실과 애도를 직면하는 것을 목표로 하며 자아가 모든 것을 통제할 수 있기를 바라고 있다. 이는 정신치료를 통해 무의식의 내용 물이 자아가 견딜 수 있는 정도로 서서히 의식화되는 것을 연상시킨다. 청소년기에는 자아가 불균등 발달 상태에 머물
러 있다. 자아의 특정 영역은 빠르게 발달하여 성인의 자아 능력에 필적하지만, 다른 영역은 소아기의 수준에 머물러 있 다. 따라서 청소년기의 자아는 상실이나 죽음과 같은 주제를 스스로 다루기에는 미흡한 면이 있고 이에 대한 반응도 성 인기의 것과 달리 예측하기 어렵다. 영화 속에서 코너는 네 번의 꿈을 통해 현실과 환상의 접점을 형성하고 자신의 자아 를 직면하게 된다. 이처럼 단계적 과정을 거치는 것은 청소 년기에 발생하는 상실과 죽음을 가장 안전하게 다루는 방식 이다. 소아 - 청소년기에 부모와 같은 중요한 대상을 잃는 것 은 자아의 발달에 큰 영향을 준다. 특히 어릴 때부터 부모의 이혼이라는 상실을 경험한 채 성장한 코너에게 있어 엄마가 병으로 임박한 죽음을 앞두고 있다는 현실은 더욱 받아들이 기 힘든 일이었을 것이다. 그러나 청소년기에는 소아기와 달 리 상실의 불가피성에 대해서 이성적으로 수용하고, 서서히 애도의 준비를 시작할 수 있는 잠재력이 있다.

일반적으로 애도는 총 네 단계의 과정으로 이루어진다. 첫 단계는 무감각과 부정의 단계로 비현실감을 느낄 수도 있다 (Bowlby와 Parkes 1970). 코너가 엄마를 떠나보내는 과정에 서 애도는 다음과 같은 과정을 거쳤다. 우선 괴물을 만나기 전 코너는 위협적인 현실을 받아들이지 않고 애도에서 물러 나 무감각하게 지내는 시기를 보낸다. 이는 커다란 상실을 경험한 사람들이 흔히 경험하는 것으로 충격적인 현실에서 일시적이지만 벗어나는 방패가 되며 ‘정서적 마취’라고 불리 기도 한다(Rando 1984). 개인은 상실 이전에 자기가 늘 살아 온 방식으로 큰 변화 없이 살아갈 것이라고 추정하는 가정된 세상(assumptive world) 속에서 살아간다(Parkes 1988). 반 복되는 꿈속에서 소년이 '지진'을 경험하는 것은 엄마의 죽 음과 청소년기로의 발달이 그전까지 살았던 익숙한 세상을 무너뜨리고 근본적인 변화를 요구한다는 것을 상징한다. 이 처럼 예측하지 못한 삶의 변화는 코너의 심상에서 천재지변 이나 재앙과 같은 존재가 된다. 인간은 경험한 것의 의미를 만들려 노력하는 존재이며(Neimeyer 2001), 꿈은 무의식이 사건의 의미를 알아내고자 하며 일어난 일을 이해하고 화해 하고자 하는 시도로 이루어지는 정신작용이다. 꿈은 애도 과 정을 시작하도록 하며(Mallon 2005; Knudson 등 2006) 애도 과정의 단계나 진전을 반영해주는 것일 수도 있다(Garfileld 1996). 이처럼 꿈에는 미래 지향적 기능이 있어서 미래에 있 을 사건에 대한 예비적인 연습이나 초안으로 기능하고 상징 성을 통하여 미래에 있을 갈등을 해결할 수 있는 방법을 제시 하기도 한다(Jung 1970). 예견된 애도 상황에서 개인은 꿈을 통해 상실을 미리 경험하기도 하는데 파크스(Parkes 1988)는 이 같은 꿈을 통한 예비 애도 과정을 “불안 완화 작업'이라고 불렀다. 이는 꿈을 통해 미리 죽음으로 인한 한 사람의 부재 
를 상상함으로써 커다란 변화를 앞당겨서 맞고 상실을 해소 하고자 하는 무의식이 작용한 결과이다. 반복되는 꿈은 코너 에게 상실과 죽음을 강렬하게 체험하게 함으로써, 억압되고 지연된 애도 과정을 촉발한다. 꿈은 근본적인 변화를 받아들 여야 한다는 것을 경고하는 동시에 코너가 상실에 압도되지 않고 상실을 다루게 될 수 있음을 암시한 것이다.

예견된 상실은 분리-개별화 과정을 촉진하는 역할을 한다. 마가렛 말러(Mahler 1974)는 모든 독립 과정에는 대상 상실 에 대한 위협이 존재한다고 했다. 상실은 대상의 내재화와 동 일시를 통하여 자아 및 초자아 발달을 촉진한다. 발달에 대한 본능적 요구는 상실로 인한 일차적 감각을 넘어서므로, 상실 의 위협이 도리어 정상 발달을 촉진할 수 있다. 괴물과 만나 기 전 코너의 자아는 상실을 감당하지 못하고 회피하려고 했 지만 이제 상실은 코너의 발달을 촉진할 수 있는 사건이 되었 다. 괴물과의 만남과 반복된 꿈은 코너의 정체된 정신의 성숙 과 발달을 가동시키는 회복본능의 작동이었을 것이다.

\section{괴물의 의미}

코너가 처음 괴물을 발견한 것은 방 안에서 창을 통해서였 다. 방 안의 코너가 현실에 속한다면, 창 밖의 주목나무가 괴 물로 변신한 것은 코너의 정신세계의 환상을 상징한다. 따라 서 창은 현실과 환상의 접점이고 현실과 환상을 넘나드는 무의식의 통로인 꿈을 의미한다. 창 밖의 괴물이 점차 집 안 으로 들어오고, 코너는 이를 위협적으로 느낀다. 괴물이 내 면 투사체일 수 있다는 것을 인식한 이후에는 괴물과 함께 자연스럽게 창 안팎을 오가게 된다. 이는 환상적 활동의 증 가로 환상과 현실의 경계가 모호해지는 청소년기의 정신 특 성을 반영한다. 잠복기(latent phase)에는 자아 및 초자아의 심리 내적인 구조의 확립과 욕동의 감소로 안정적인 내적 항상성을 갖지만 청소년기에 접어들면서 기존의 내적 항상 성은 다시 위협을 받는다. 안나 프로이트(Freud 1960)는 청 소년기는 평화로운 성장기의 중단이며 심리적 구조 안에서 부조화가 정상적인 것이 되는 단계라고 하였다. 멜라니 클라 인(Klein 1932)은 잠재기와 청소년기를 비교하면서, 청소년 들은 욕동의 움직임에 대하여 강력한 지배를 받는다는 점과 풍부한 환상적 활동을 한다는 점에서 오히려 잠재기 이전의 어린 아동과 유사성을 지닌다고 하였다(Klein 1932). 이처럼 청소년기 동안에는 가장 초기 유아기 단계로의 전환이 일어 나고 개인은 새로운 환경 위에서 생애 초기의 발달 과정을 다시 한 번 거치게 된다(Jones 1923).

아동과 청소년기에는 강화된 환상 활동의 일환으로 상상 친구(imaginary companion)를 갖는 경우가 많다. 상상친구 는 환상과 현실의 경계 안에서 물리적인 공간을 차지하고
있다는 점에서 다른 환상과 구별되는 특성이 있는데(Nagera 1969), 영화 속 괴물도 이 같은 상상친구의 특성을 지녔다. 상상친구의 역할은 원시적인 자아 이상(ego ideals)을 가장한 것으로 초자아의 선구자나 보조자로 기능하여 더 이상 받아 들일 수 없는 욕동을 방출하거나 현실에서 감당하기 어려운 외부 실체를 보완해 신경증 발생을 일시적으로 방어하는 수 단이 된다(Freud 1938; Fraiberg 1959). 상상친구는 일반적으 로 청소년기보다 연령대가 낮은 학령전기(preschool age)에 경험하는 현상으로 청소년기에 진입하는 코너의 상황에 대 입하는 것은 다소 무리일 수 있다. 하지만, 코너가 미숙한 심 리기제를 보이며, 전반적 발달이 정체되어 있다는 것, 고립 되어 생활을 하였다는 점들을 고려하여 괴물이 상상친구의 기능을 했다고 해석하는 것은 가능하다고 판단한다. 코너의 고통스러운 현실과 발달에 대한 본능은 이런 환상들을 촉발 시켜, 괴물이라는 상상친구를 불러낸 것이라고 할 수 있다. 두 번째 꿈에서 괴물의 권유로 억압되었던 코너의 공격성이 폭발하여 행동화로 이어지는 것도 상상친구의 기능에 부합 한다. 엄마의 예견된 죽음을 받아들이는 것과 청소년기의 심 리적 변화는 이제까지 소년이 이해하던 세계를 붕괴시키기 에 충분했다. 이 같은 한계 상황에서 익숙했던 정신세계의 형태를 파괴하는 것은 오히려 상실의 적극적인 수용이며 다 음 단계로의 발달이 시작되었음을 의미한다. 벤슨과 프라이 어(Benson과 Pryor 1973)는 상상친구의 환상에 대한 이해 를 돕기 위해 위니코트(Winnicott)와 코흐(Kohut)의 정신분 석적 이론의 틀을 채택했다. 이들에 따르면, 상상친구는 발 달 기능을 수행하는 자기 객체라는 점에서 일련의 자기애적 보호자들(narcissistic guardians) 중 하나다. 이들은 완전함의 감각을 진정시키고 반영함으로써 자기애적 상해로부터 보호 한다. 또 자기 통합에 위협이 되지 않으면서도 안전하게 대상 을 사랑할 수 있는 수준까지 발전하게 해 준다(Kohut 1971). 이와 비슷한 기능은 과도기적 대상(transitional object) (Winnicott 1953)의 역할과도 유사하다. 영화 속에서 괴물은 이 같은 기능들을 충실히 수행하면서 코너가 엄마의 예견된 죽음을 애도하고 더 높은 수준으로 발달하도록 돕는다.

프로이트(Freud 1917)는 애도와 우울증은 나타나는 양상 이 동일하고 양쪽 다 사랑하는 대상의 상실에 기인한다는 점 때문에 서로 연관이 있다고 했다. 모든 애도 과정에는 홀로 남겨지고 상실과 타협하여 어쩔 수 없이 삶을 새롭게 꾸려야 만 하는 상황에 대한 분노가 내재되어 있다. 이처럼 애도 과 정은 필연적으로 공격성이 드러나야 하지만 죽은 자를 나쁘 게 이야기해서는 안 된다는 불문율에 따라 공격성을 억압해 야 하는 모순이 발생한다(Kast 1982). 상실과 관련된 분노와 죄책감은 본격적인 탐색의 과정이며 자기 이해의 측면이 있 
다(Bowlby 1980). 코너는 괴물을 통하여 숨겨왔던 자신의 공격성과 죄책감을 인정하고 적절히 표출하는 과정을 통하 여 완전함의 감각을 되찾는다. 이 같은 통합은 코너가 병적 인 죄책감과 억압에서 벗어날 수 있게 하였다. 다른 한편으 로 괴물은 치료적 대상관계를 반영한다. 안아주는 환경 (holding environment) (Winnicott 1953)과 치료적 대상관 계(Grunes 1984)를 통해서 애도 과정이 촉진될 수 있다. 괴 물이라는 상상친구는 코너의 고통에 공감하고, 말로 표현할 수 있도록 했으며 코너가 외면했던 자신의 내면을 느끼고 관 찰하도록 도왔다. 괴물과의 대상관계는 코너가 애도를 진전 시키는 데 있어 필요한 핵심적인 연결이 되었으며 안아주는 환경으로도 기능했다. 코너는 괴물과 관계를 통하여 애도 과 정을 거치면서 정체된 상태에서 벗어나 발달을 향해 나아갈 수 있었다. 이와 같이 상상친구는 보호 및 발달의 장치가 되 지만, 병적으로 지속될 경우에는 오히려 환상에 중독되어 현 실의 관계를 저해하는 부정적인 요소가 된다(Adamo 2004). 이런 측면을 반영하여 괴물은 소년을 적당한 시기에 떠난다. 이별하기 전, 소년이 괴물에게 함께 있어 줄 것인지에 대해 서 묻자 괴물은 "여기 있으마."라고 대답한다. 이는 정신치료 에서 환자가 치료자를 내면화(internalization of therapists) 하는 과정을 떠오르게 한다. 괴물은 소멸된 뒤에도 코너의 내면에서 기능하여 발달적 애도 과정을 지속적으로 수행하 게 도울 것이다. 필연적인 이별을 받아들인다는 것은 더욱이 코너가 본격적인 청소년기로 진입하여 스스로 자아 기능을 수행할 수 있을 만큼 성장하였음을 반영한다. 또한, 괴물이 성장을 이끌어가는 관찰자 자아(observing ego)의 역할을 하 거나, 인지 발달에서 메타인지적 역할을 한 것으로, 괴물이 떠나면서 코너의 심상에 내재화되는 것으로 청소년기의 적 절한 성장 단계로 들어간 것을 의미하기도 한다.

내면화된 치료자들은 자기 검열(self-examination)과 강화 된 자아 인식(self-awareness)을 통해 지속적으로 영향을 준다 (Singer와 Pope 1978). 많은 이론가들은 치료자에 대한 내적 표상이 치유 과정에 있어서 핵심적인 요소라고 한다. 또 치료 적으로 중요한 많은 부분들은 환자의 내부에서 치료자에 대한 인지 및 정서적 표상들이 지속적으로 촉발되고 재활성화되는 과정을 통해서 이루어진다는 점에 동의한다(Loewald 1960; Kohut 1971).

\section{청소년기 인지 발달 측면에서 꿈}

죽음은 비가역성, 종결성, 불가피성, 인과성이라는 네 가 지 요소를 특성으로 갖는다(Mallon 2011). 일반적으로 인지 의 성숙은 개인이 죽음이라는 개념을 이해하는 데 있어 큰 영 향을 준다. 자신의 나쁜 생각 때문에 엄마가 죽게 되었다는
코너의 믿음은 일종의 마술적 사고로, 아직 코너가 청소년기 의 인지적 단계에 진입하지 못한 것을 반영한다. 죄책감은 애 도자가 더 이상 애도 과정을 진행할 수 없게 하며 명백히 상실 된 대상과의 관계에서 발생하는 산물이기 때문에 해결되어야 한다(Kast 1982). 괴물은 코너에게 어떤 생각을 하는지는 중요 하지 않으며, 어떤 행동을 하는지가 중요하다는 것을 말하며 코너가 죄책감에서 벗어날 수 있도록 유도한다.

첫 번째 꿈에는 성왕이지만 살인을 저지르기도 한 왕자와 악인으로 보였지만 실상은 그렇지 않은 왕비가 등장한다. 두 번째 꿈에는 사람들에게 외면받는 약제사와 사람들의 존경 을 받는 목사가 등장하지만 정작 신념을 저버리는 것은 목사 이다. 괴물은 코너에게 세상에는 완벽한 악인이나 완벽한 선 인이 없으며 모두 그 중간에 위치해 있다고 한다. 또 세상에 는 거짓 같은 진실이 존재한다고 말한다. 괴물이 들려주는 혼란스러운 이야기는 코너가 처한 복잡한 상황과 닮아 있다. 코너의 엄마는 자신이 죽게 될 것을 알면서도 코너에게 자신 의 죽음을 대비해야 한다는 말을 차마 하지 못한 채 자신의 죽음을 부정한다. 코너는 예견된 애도 상황이 주는 고통을 견딜 수 없어서 차라리 엄마가 죽고 이 모든 상황이 끝나기 를 바라는 동시에 엄마와 함께했던 과거의 행복한 삶으로 돌 아가기를 원한다. 인간은 관계를 통해서 자신을 이해할 수 있다. 관계는 자기 체험과 세계 체험의 본질이며, 사랑하는 사람의 죽음은 이제까지 이해하고 있던 자기와 세계를 교란 시킬 수 있다(Kast 1982). 코너의 인지능력과 도덕적 체계는 애도 상황과 자신을 이해할 수 있는 충분한 자원을 제공하지 못했다. 이에 코너는 방어적으로 자신을 분열시킨 채 스스로 도 종잡을 수 없는 혼란을 겪었다. 이때 등장한 괴물은 이야 기를 통해서 소년의 인지 및 도덕적 판단의 발달을 유도한다. 코너가 이야기를 이해했다는 것을 통해서 소년의 인지와 도 덕적 판단 능력이 성숙했다는 것을 확인할 수 있다. 특히 두 번째 이야기는 콜버그가 자신의 연구에서 도덕적 발달 수준 의 측정을 위해 사용한 하인즈 딜레마(Heinz dilemma)와 매 우 유사하다. 청소년기가 되면 이전보다 인지능력이 성숙되 고 사고의 복잡성이 증가하면서 메타 인지, 자기 반추 기능, 양가성 등을 이해하고 설명하는 능력을 갖게 된다(Fonagy 와 Target 1997). 인지능력의 발달로 청소년은 죽음의 네 가 지 요소를 이해하고 삶과 죽음의 의미, 자기 정체성 등에 대 한 고민을 할 수 있는 능력을 갖게 되지만 이에 수반되는 강 렬한 감정을 다루는 것은 아직 힘들 수 있다(Mallon 2010). 장 피아제(Piaget 1932)는 도덕적 추론과 판단에 관한 일련 의 연구를 통해 인지능력의 성숙이 도덕적 추론과 판단의 성숙을 유발한다고 주장했다. 그는 약 11 세 이전의 아동들은 규범이나 법률을 전지전능한 신이나 어른이 만든 것으로 판 
단하고 이에 복종하는 것이 최고의 선이라고 믿는 타율적 도 덕 판단의 단계를 보인다고 하였다. 그 이후 규범이나 법칙에 대해 이전보다 융통성 있게 생각하게 되어 도덕적 판단을 함 에 있어 상황적 요인을 고려하는 도덕적 상대주의 또는 도덕 적 호혜주의에 근거하게 된다. 콜버그(Kohlberg 1984)는 이 같은 피아제의 이론을 보다 확장하여 발달 단계 이론을 제시 하였다. 콜버그는 관습적 도덕 수준(conventional level)에서 는 타인의 기대나 사회적 질서에 순종하여 착한 행동을 하 는 것과 인습적인 사회질서를 유지하는 것을 도덕으로 정의 한다고 하였다. 그러나 제반 윤리이론에 대한 보다 깊이 있 는 통찰이 이루어지는 관습 후기(postconventional level)가 되면 법률을 절대적인 것이 아닌 하나의 사회적 계약이라고 생각하게 되고 도덕적 가치와 원칙을 스스로 정의한다. 처음 코너가 꿈속에서 엄마의 손을 놓은 자신을 용납하지 못하고 '착한 아이'를 지향하는 것은 타율적이고 관습적인 도덕 수 준 상태에 머물러 있었음을 보여준다. 괴물과 만나 죽음을 애도하는 일련의 과정을 거치면서 코너의 인지 및 도덕적 발달이 촉진되었다. 그 결과 죽음을 이해할 수 있는 인지적 인 성숙과 관습 후기 수준의 도덕적 발달을 이루었다.

\section{투명인간: 자아 정체성의 형성, 동료 집단에 합류}

코너에게 있어 동료들이 자신을 투명인간으로 여기는 것 은 실제 폭력을 당하는 것보다 더 큰 고통이며, 분노 반응을 유발했다. 청소년기의 주요한 과제는 정체성의 확립이며 그 기반은 존재감이다. 청소년기의 정체성은 평판을 통해서 획 득되거나 유지되는 면이 많다. 따라서 부정적인 평판이라고 해도 존재감은 가질 수 있기에 오히려 긍정적 요소로 인식되 기도 한다. 그래서 일부 청소년은 악행을 저질러 집단 내에서 자신의 위치를 분명히 하면서 존재감을 확보하려고 노력하 기도 한다. 코너의 자아가 가장 취약하게 느낀 것은 바로 자 신의 존재감이었다. 코너는 해리를 라이벌로 인식하며 비교 속에서 존재감을 확인하려 했다. 그러나 해리가 도리어 자신 의 존재를 무시하자 정체성 형성의 큰 위기를 느끼고 분노를 폭발했다. 자아의 발달과 정체성의 형성은 전 생애를 거쳐 이 루어지지만, 청소년기는 정체성 형성에 있어서 가장 중심이 되는 시기이다(Erikson 1968; Demo와 Savin-Williams 1992). 초기 청소년기는 강화된 자기 집중, 내적 성찰 및 자의식이 특 징이며(Demo와 Savin-Williams 1992) 이를 바탕으로 자신의 체계(self system)를 다시 검토하고 개정할 수 있다. 에릭슨 (Erikson 1968)은 청소년들이 자아 정체성과 관련하여 겪는 정신적인 갈등과 고통을 '정체성의 위기(identity crisis)'라고 칭하며 이를 병리적인 현상이 아닌 자신을 새롭게 정립하기 위한 하나의 발달 과정으로 보았다.
초기 청소년기에 나타나는 두 가지 발달은 자아 정체성의 형성을 촉발한다. 첫째, 추상적 인지와 인식능력의 성장을 통 해서 스스로 자신을 어떻게 보는지, 다른 사람들이 그들을 어 떻게 인식하는지에 대한 맥락을 제공받는다(Harter 1999). 둘 째, 상대적으로 평등한 관계가 주는 안전과 안락함 속에서 우정과 친밀감을 형성하면서(Duff 1996; Seginer 1992) 자아 탐구 및 평가가 이루어진다(Sullivan 1953). 청소년은 부모 로부터의 독립을 추구하며 자신의 개성을 탐색하는 동시에 또래의 인정과 지지를 위한 동조의 중요성을 인식한다. 또래 집단(peer group)은 청소년이 자신의 정체성을 탐색하고 점 검하는 도구가 되며 존재 가치를 확인하는 귀중한 준거가 된 다. 이처럼 청소년기에는 자기 정체성을 갖고자 하는 동시에 타인에게 예속되려는 내적인 모순이 발생하는데, 이는 독립 과 동조라는 두 가지 필요성을 통합해 정체성을 확립하는 정 상적인 과정이다. 코너에게 있어 투명인간이 되었다는 것은 정체성의 상실을 의미할 뿐만 아니라, 또래 집단을 통하여 자신의 정체성을 형성할 수 있는 중요한 기회를 박탈당한 것 을 의미한다. 그래서 그처럼 강렬한 폭력적 행동화가 유발되 었던 것이다.

\section{애도의 완성은 동일시}

영화의 말미에서 코너는 엄마가 사망한 이후 외할머니와 함께 살게 되고, 엄마가 어릴 때 쓰던 방을 물려받는다. 에필 로그 격인 이 장면은 코너가 엄마와 자신을 동일시(identification)하는 것으로 애도를 대신하고 있다는 것을 상징한 것 이다. 애도는 상실을 받아들이고 계속 살아가도록 할 뿐만 아니라 대상의 상실을 의식에 통합하고 상실된 대상과의 경 험을 삶의 한 부분으로 받아들이도록 한다. 계속되는 결속 (continuing bonds)은 사별을 경험한 사람이 고인의 죽음 이 후에도 고인과 서로 연결되어 있다고 믿는 것으로 그것이 미 래의 삶에 영향을 준다(Holland 2001). 이처럼 계속되는 결 속을 통해 자기의 삶에 고인을 포함시키게 되면 죽음은 더 이 상 관계의 종말을 의미하지 않을 수 있다(Strokes 2004). 애도 에 관한 최근의 개념은 망자에 대한 분리만을 강조했던 프로 이트를 포함한 초기 이론가들의 주장과는 달리, 죽은 자와의 결속을 푸는 것과 애착을 유지하는 것을 포함한다(Klass 등 2014). 따라서 애도를 '상실을 향함(loss orientation)'과 '회복을 향함(restoration orientation)'의 진동 모델(oscillation model) 로 보는 것이다(Stroebe와 Schut 1999).

워든(Worden 1991)은 상실 후 거쳐야만 하는 일련의 심 리적 과제들이 있다는 생각을 기반으로 애도의 4단계의 과제 모델을 제시하였고, 랜도(Rando 1993)는 이를 보다 발전시켜 '재적응의 단계'를 추가했다. 재적응의 단계는 예전의 애착을 
잃지 않으면서 새로운 정체성을 형성하고 삶에 재투자하는 것을 의미한다. 애도 과정은 개별적인 동시에 고인과 연결된 존재로서의 자신을 발견할 수 있는 가능성을 열어주며, 고인 이 산 사람이 의지할 수 있는 능동적이고 긍정적인 자원이 되 도록 한다(Riches와 Dawson 2000). 성공적인 애도 과정을 통 해 코너는 엄마의 죽음을 망각하지 않은 채로 이를 적절히 수 용하고 새로운 개별화의 방향으로 나아갈 수 있었다.

\section{결 론}

영화 '몬스터 콜'은 청소년기로 이행하는 격변기와 엄마의 죽음을 동시에 맞이하는 한계적 상황에서, 한 소년이 괴물이 라는 상징적인 대상을 통해 청소년기의 발달과 애도를 수행 하는 과정을 보여줬다. 이는 상실이 발달을 촉발하며 죽음이 새로운 삶을 창조한다는 정신분석적 시각에 부합한다. 저자 들은 '몬스터 콜'을 응용 정신분석의 재료로 다루면서 강화된 환상, 애착 대상에 대한 점진적인 분리 및 제2 개별화, 인지 및 도덕적 판단 능력의 성숙, 자아 정체성의 형성, 동료 집단 에의 합류 등과 관련하여 청소년기의 발달적 특성을 이해할 수 있는 풍부한 자원을 얻을 수 있었다. 또한 연구를 통하여 정신분석에서 주요한 주제가 되어 온 애도의 본질에 대한 이 해를 넓혔으며 발달적 애도에 대한 통찰을 얻었다. 에리히 프롬(Fromm 2002)은 인간이 죽음보다 생명을 사랑하고, 과 거에 머무르기보다는 새로운 것을 창조하는 것을 생애 지향 (biophillie)이라고 하였다. 애도가 갖는 핵심적 의의는 이 같 은 생애 지향에 있다. 즉, 애도는 단순히 상실을 견뎌내는 것 이 아니라, 자신을 새롭게 경험하고 재구성하면서 상실과 죽 음을 자신의 일부가 되게 하여 보다 높은 수준의 발달과 성 숙을 이끌어내는 창조적인 과정이다. 우리가 영화를 통해서 주인공의 심리를 이해하고 공감하는 등 실제적인 경험에 견 줄 수 있는 체험을 할 수 있는 이유는 이 같은 발달과 성숙의 요구가 비단 청소년기에만 국한되지 않기 때문이다. 삶의 과 정 속에서 개인이 경험하는 불가피하고 고통스러운 상실의 과정은 자기 성장을 위한 도전이 되어야 한다. 이번 연구를 통해서 상실의 불가피성과 인생의 유한성을 받아들이고 잃 어버린 대상을 내재화하며 동일시하는 애도 과정을 거치는 것은 인간의 발달과 성숙에 있어서 필수적인 요소라는 것을 알 수 있었다.

\section{Conflicts of Interest}

The authors have no financial conflicts of interest.

\section{REFERENCES}

Adamo S. An adolescent and his imaginary companions: from quasi-de- lusional constructs to creative imagination. J Child Psychother 2004; 30:275-295.

Benson RM, Pryor DB. "When friends fall out": developmental interference with the function of some imaginary companions. J Am Psychoanal Assoc 1973;21:457-473.

Blos P. The second individuation process of adolescence. Psychoanal Study Child 1967;22:162-186.

Bowlby J. Pathological mourning and childhood mourning. J Am Psychoanal Assoc 1963;11:500-541.

Bowlby J. Attachment and loss: vol. 1. Attachment. New York, NY: Basic Books;1969.

Bowlby J. Attachment and loss: vol. 3. Loss-sadness and depression. New York, NY: Basic Books;1980.

Bowlby J, Parkes CM. Separation and loss within the family. In: Anthony EJ, Koupernik CJ. The child in his family. New York/Chichester: Wiley;1970. p.197-216.

Bukowski WM, Hoza B. Popularity and friendship: issues in theory, measurement, and outcome. In: Berndt TJ, Ladd GW. Peer relationships in child development. New York, NY: Wiley;1989.

Demo DH, Savin-Williams RC. Self-concept stability and change during adolescence. In: Lipka RP, Brinthaupt TM. Self-perspectives across the life span. Albany, NY: State University of New York Press;1992. p.116-148.

Duff JL. The best of friends: exploring the moral domain of adolescent frienship [unpublished doctoral dissertation]. Stanford, CA: Stanford University; 1996.

Erikson EH. Identity, youth, and crisis. New York, NY: W. W. Norton \& Company; 1968.

Fonagy P, Target M. Attachment and reflective function: their role in self-organization. Dev Psychopathol 1997;9:679-700.

Fraiberg S. The magic years: understanding and handling the problems of early childhood. New York, NY: Scribner, 1959.

Freud A. The ego and the mechanisms of defence. New York, NY: International Universities Press; 1938.

Freud A. Probleme der Pubertät [Problems of adolescence]. Psyche: Zeitschrift für psychologische und medizinische Menschenkunde; 1960. p.1-24.

Freud S. Mourning and melancholia. The standard edition of the complete psychological works of Sigmund Freud, Volume XIV (1914-1916): on the history of the psycho-analytic movement, papers on metapsychology and other works. London: Hogarth Press;1917. p.237-258.

Fromm E (Trans. Whang MS). Die seele des menschen. Ihre fähigkeit zum guten und zum bösenc (1979). Seoul: Moonye Publishing Co., Ltd.; 2002.

Garfield P. Dreams in bereavement. In: Barrett D. Trauma and dreams. Cambridge, MA:Harvard University Press;1996. p.186-211.

Grunes M. The therapeutic object relationship. Psychoanal Rev 1984; 71:123-143.

Harter S. The construction of the self: a developmental perspective. NewYork, NY:Guilford Press;1999.

Holland J. Understanding children's experiences of parental bereavement. London: Jessica Kingsley Publishers; 2001.

Jones E. Einige probleme des jugendlichen alters. Imago 1923;9:145-168.

Jung CG (edited and trans. Adler G, Hull RFC). The structure and dynamics of the psyche (Collected works of CG Jung, Volume 8). Princeton, NJ: Princeton University Press; 1970. p.255.

Kast V. Trauern. Phasen und chancen des psychischen prozesses. Kreuz, Stuttgart; 1982.

Kavaler-Adler S. Mourning, spirituality and psychic change: a new object relations view of psychoanalysis. London: Routledge;2004.

Klass D, Silverman PR, Nickman S. Continuing bonds: new understandings of grief. Washington, DC: Taylor \& Francis;2014

Klein M. The psychoanalysis of children. London: Hogarth Press;1932. p.1-379. 
Klein M. Mourning and its relation to manic-depressive states. Int J Psychoanal 1940;21:125-153.

Knudson RM, Adame AL, Finocan GM. Significant dreams: repositioning the self narrative. Dreaming 2006;16:215-222.

Kohlberg L. The psychology of moral development: the nature and validity of moral stages (Essays on moral development, Volume 2). San Francisco, CA: Harper and Row; 1984.

Kohut $\mathbf{H}$. The analysis of the self: a systematic approach to the psychoanalytic treatment of narcissistic personality disorders. London: Hogarth Press; 1971

Loewald HW. On the therapeutic action of psycho-analysis. Int J Psychoanal 1960;41:16-33.

Mahler MS. On the first three subphases of the separation-individuation process. Psychoanalysis and Contemporary Science 1974;3:295-306.

Mahler MS, Pine F, Bergman A. The psychological birth of the human infant: symbiosis and individuation. New York, NY: Basic Books, 1975.

Mallon B. Dreams and bereavement. Bereavement Care 2005;24:43-46.

Mallon B. Working with bereaved children and young people. London: SAGE Publications;2010.

Mallon B. Working with bereaved children an young people. London: SAGE Publications;2011. p.19.

Nagera $\mathbf{H}$. The imaginary companion. Its significance for ego development and conflict solution. Psychoanal Study Child 1969;24:165-196.

Neimeyer RA. Meaning reconstruction \& the experience of loss. Washington, DC: American Psychological Association, 2001.

Ness P. A monster calls. London: Walker Books;2011.

Paikoff RL, Brooks-Gunn J. Do parent-child relationships change during puberty? Psychol Bull 1991;110:47-66.
Parkes CM. Bereavement as a psychosocial transition: processes of adaptation to change. Journal of Social Issues 1988;44:53-65.

Piaget J. The moral judgment of the child. London: K. Paul, Trench, Trubner \& Co. 1td.;1932.

Rando TA. Grief, dying, and death: clinical interventions for caregivers (Vol. 2324). Champaign, IL: Research Press Publishers; 1984.

Rando TA. Treatment of complicated mourning. Champaign, IL: Research Press Publishers; 1993.

Riches G, Dawson P. An intimate loneliness: supporting bereaved parents and siblings. Maidenhead: McGraw-Hill Education (UK);2000.

Seginer R. Sibling relationships in early adolescence: a study of Israeli Arab sisters. J Early Adolesc 1992;12:96-110.

Singer JL, Pope KS. The use of imagery and fantasy techniques in psychotherapy. In: Singer JL, Pope KS. The power of human imagination: new methods in psychotherapy. Boston, MA: Springer;1978. p.3-34.

Stokes JA. Then, now and always: supporting children as they journey through grief: a guide for practitioners. Cheltenham: Winston's Wish; 2004.

Stroebe M, Schut H. The dual process model of coping with bereavement: rationale and description. Death Stud 1999;23:197-224.

Sullivan HS. The interpersonal theory of psychiatry. New York, NY: Norton; 1953.

Weiss RS. Chapter 4. The attachment bond in childhood and adulthood. In: Parkes CM, Stevenson-Hinde J, Marris P. Attachment across the life cycle. London: Routledge;1991. p.66-76.

Winnicott DW. Transitional objects and transitional phenomena; a study of the first not-me possession. Int J Psychoanal 1953;34:89-97.

Worden JW. Grief counselling and grief therapy: a handbook for the mental health practitioner. London: Routledge; 1991. 